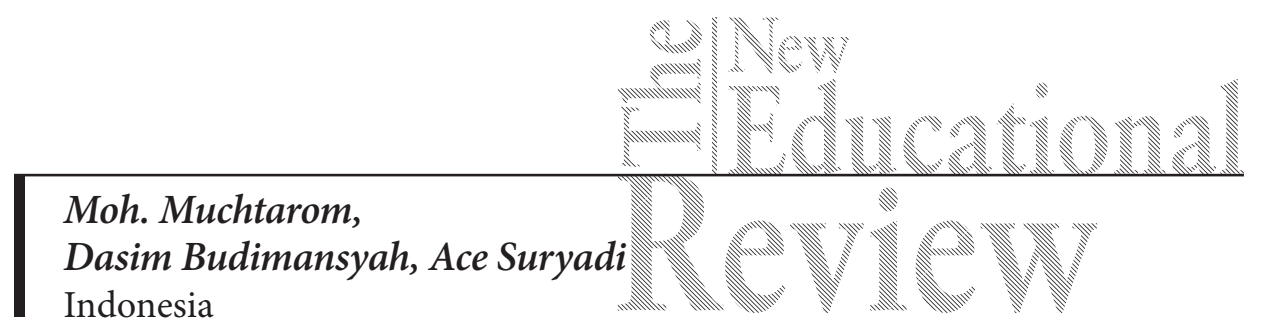

\title{
The Implementation of Integrated Education to Develop the Intact Personality of Students
}

DOI: 10.15804/tner.2016.43.1.12

\begin{abstract}
The objective of this study was to describe the implementation of integrated education in Nur Hidayah Islamic Integrated Senior Secondary School of Sukoharjo, Central Java, Indonesia. It used the analytic descriptive-qualitative method with the case study approach. There are seven main principles of integration in the learning process, namely: integration of human potentials, integration of institutions, integration of curriculum, integration of learning domains, integration of three centers of education, integration of theory and practice, and integration of learning activities. The impact of the integrated education can form intact personality which encompasses religiosity, morality, intellectuality, high motivation, leadership, healthy lifestyle, self-reliance, work ethics and discipline, and socio-political awareness. Thus, models of integrated education can be implemented in senior secondary schools.
\end{abstract}

Keywords: integrated education, principles, intact personality

\section{Introduction}

Integrated education treats the student as a whole human being. The goal is not only to create a superior human being based on the physical matter ,but also to develop an integrated personality of a human being. Some aspects that exist in human beings, such as mind, spirit, emotion, and physicality, should be developed simultaneously and integrated perfectly in human beings (Fan, 2004). Whitehead believes that the relation of all aspects of human life is one reality and 
it is fundamentally interrelated. "Everything in this world is interconnected"; each is part of the overall (Evans, 1998, p. 12). The idea of integrated education is not only to educate people to become smart but more importantly to make people become good human beings. The integrated educational process implies not only the transfer of knowledge, but also the transfer of values and attitudes.

However, the substance of educational practices is frequently alienated, where education just becomes an institution which enlightens the intellect and mind but ignores the potentials of students' mind or mentality. The learning process is dominated by the memorization method with textual approaches so it can eliminate the meaning and context of learning itself. Al-Attas (JSIT, 2010, p.x) states that today, educational models have lost the spirit of inquiry due to the educational models which are based on the view of the $19^{\text {th }}$ century, based on the reductionist, linear thinking (non-systemic learning), and positivism (physical emphasis learning), which makes it difficult for students to understand the meaning and value between what they learn in their school and what they learn in society (Rubiyanto and Haryanto, 2010, p. 31).

The decline in this inquiry results in monotonous, boring, and one-way learning and teaching activities at schools, which make it impossible to develop methods that train and empower students' ability. As a result, the learning models are fixed on the memorization method, and careful listening method, not developing discussion, seminar, case study, problem solving, experiment, observation, etc. Students become less skillful in facing various problems and challenges of life.

The impact of the educational process mentioned above produces intellectually smart students, but they might have less morality, poor spirituality, and they cannot develop creativity. Therefore, such an education can only create human beings with split personality, whereas it should create a human being with intact personality and become a means of developing intellect, creativity, morality, and religiosity.

\section{Research Methodology}

The presented research used the qualitative approach, which is also known as a mode of qualitative interactive inquiry, according to Sukmadinata (2008, p. 61). It used the analytical descriptive method in the form of case study. Its subjects were: a school principal, teachers, students, students' parents, and the alumni of Nur Hidayah Islamic Integrated Senior Secondary School Sukoharjo, Central Java, Indonesia. It researched the impact of integrated education on the formation of the intact personality of students. 
The researcher acted as a human instrument or a key instrument. Data were collected through (1) observation, (2) in-depth interview, and (3) document study. To analyze the data, the researcher used three simultaneous and interrelated components of activities, as suggested by Miles and Huberman (Alwasilah, 2011, p.119), namely: data reduction, data display, and conclusion drawing or verification.

\section{Research Results}

\section{Integrated Education Principles}

The implementation of integrated education at Nur Hidayah Islamic Integrated Senior Secondary School of Sukoharjo involved the seven main principles of integrated education at schools, namely: integration of human potentials, integration of institutions, integration of the curriculum, integration of learning domains, integration of three centers of education, integration of theory and practice, and integration of learning activities.

Table 1. The Main Principles of Integrated Education

\begin{tabular}{|c|c|c|}
\hline $\begin{array}{c}\text { Integrated } \\
\text { principles }\end{array}$ & Description & Activities \\
\hline $\begin{array}{l}\text { 1. Human } \\
\text { potentials }\end{array}$ & $\begin{array}{l}\text { The integration of spirit, } \\
\text { mind, and physicality }\end{array}$ & $\begin{array}{l}\text { - included in the vision and mission of schools } \\
\text { - included in the curriculum } \\
\text { - Arranging the program of integrated activities }\end{array}$ \\
\hline $\begin{array}{l}\text { 2. Institu- } \\
\text { tions }\end{array}$ & $\begin{array}{l}\text { Management of inte- } \\
\text { grated and sustainable } \\
\text { (hierarchical) education }\end{array}$ & $\begin{array}{l}\text { - Arranging the integrated and hierarchical curriculum } \\
\text { - Fostering the students by mentoring } \\
\text { - Managing the centralized finance } \\
\text { - Fostering the teaching staff and administration staff }\end{array}$ \\
\hline $\begin{array}{l}\text { 3. Curricu- } \\
\text { lum }\end{array}$ & $\begin{array}{l}\text { Integrating national } \\
\text { curriculum with Islamic } \\
\text { teaching contents or } \\
\text { islamization of curric- } \\
\text { ulum }\end{array}$ & $\begin{array}{l}\text { - Classifying the subjects into five groups (Religion, } \\
\text { Mathematics and Science; Social Science, History, } \\
\text { and Civics; Language; Information and Computer } \\
\text { Technology) } \\
\text { - Islamization of Standard/Basic Competences (SKKD) } \\
\text { by developing, equipping, and incorporating the Is- } \\
\text { lamic values in the SKKD which is formulated by the } \\
\text { National Education Standard Agency (BSNP) } \\
\text { - Adding and Completing the Basic Competences } \\
\text { - Islamizing the content and learning materials } \\
\text { - Islamizing the learning process by using materials, } \\
\text { methods, tools media, and learning evaluation by } \\
\text { incorporating the Islamic values. }\end{array}$ \\
\hline
\end{tabular}




\begin{tabular}{|c|c|c|}
\hline $\begin{array}{c}\text { Integrated } \\
\text { principles }\end{array}$ & Description & Activities \\
\hline $\begin{array}{l}\text { 4. Learning } \\
\text { domains }\end{array}$ & $\begin{array}{l}\text { Integrating the entire } \\
\text { domains of the learning } \\
\text { goal to achieve compe- } \\
\text { tences in the cognitive, } \\
\text { affective, and conative } \\
\text { competences }\end{array}$ & $\begin{array}{l}\text { - Applying the learning models that accommodate } \\
\text { multiple intelligences, namely: intellectual, spiritual, } \\
\text { emotional, social, and kinesthetic intelligences } \\
\text { - Appreciating each competence of the students (all } \\
\text { students are champions) } \\
\text { - Applying an integrated evaluation and deleting rank- } \\
\text { ing system. }\end{array}$ \\
\hline $\begin{array}{l}\text { 5. Three } \\
\text { centers of } \\
\text { education }\end{array}$ & $\begin{array}{l}\text { Cooperation among } \\
\text { schools, parents, and } \\
\text { society }\end{array}$ & $\begin{array}{l}\text { - Delegating the socialization of the education system } \\
\text { to the parents } \\
\text { - Developing collective commitment to make the } \\
\text { school's program succeed } \\
\text { - Delivering the learning result reports in the middle } \\
\text { and at the end of each semester. } \\
\text { - Giving "life report" every month to the students } \\
\text { - Involving the parents in fostering "troubled" students } \\
\text { - Developing a communication network } \\
\text { - Facilitating the parents' organization } \\
\text { - Involving the parents in social activities, learning, and } \\
\text { events of student creativity } \\
\text { - Inviting the parents to a parenting seminar } \\
\text { - Establishing cooperation with government institu- } \\
\text { tions and security forces } \\
\text { - Conducting social events that involve the community } \\
\text { - Making the environment become a means of learning } \\
\text { and learning sources } \\
\text { - Doing demonstration activities at certain moments } \\
\text { - Tarhib or welcoming a fasting month to give educa- } \\
\text { tional intervention to the public } \\
\text { - etc }\end{array}$ \\
\hline $\begin{array}{l}\text { 6. Theory } \\
\text { and prac- } \\
\text { tice }\end{array}$ & $\begin{array}{l}\text { The integration of } \\
\text { theory and practice, } \\
\text { textual and contextual, } \\
\text { knowledge and direct } \\
\text { experience in learning }\end{array}$ & $\begin{array}{l}\text { - Praying together } \\
\text { - Eating together } \\
\text { - Administering nights of faith and taqwa development } \\
\text { (MABIT) } \\
\text { - Class outing } \\
\text { - Creating students' organizations } \\
\text { - Celebrating the national and Islamic holidays } \\
\text { - Social events } \\
\text { - Creating honesty canteen } \\
\text { - Mentoring } \\
\text { - Conducting scouting activities } \\
\text { - etc }\end{array}$ \\
\hline
\end{tabular}




\begin{tabular}{|c|c|c|}
\hline $\begin{array}{l}\text { Integrated } \\
\text { principles }\end{array}$ & Description & Activities \\
\hline $\begin{array}{l}\text { 7. Learning } \\
\text { activities }\end{array}$ & $\begin{array}{l}\text { The learning process } \\
\text { is described in the } \\
\text { intra-curricular, co-cur- } \\
\text { ricular, and extracurric- } \\
\text { ular activities designed } \\
\text { in an integrated manner }\end{array}$ & $\begin{array}{l}\text { Intra-curricular activities are done in the form of cur- } \\
\text { riculum islamization (objectives, methods, materials, } \\
\text { media, tools, and evaluation of learning); preparing } \\
\text { learning that can develop cognitive, affective, and psy- } \\
\text { chomotor abilities; and preparing learning activities } \\
\text { that provide theoretical-practical, textual, and contex- } \\
\text { tual foundations: knowledge and direct experiences in } \\
\text { students' life. } \\
\text { - Co-curricular activities are conducted in the forms } \\
\text { of class outing, scientific visits, praying-together activ- } \\
\text { ities, MABIT, outing bond, academic and non-aca- } \\
\text { demic competitions, tsaqafah (Islamic organization) } \\
\text { activity, etc. } \\
\text { - Extracurricular activities are administered in the } \\
\text { form of compulsory extracurricular activities (men- } \\
\text { toring and scouting), and optional extracurricular } \\
\text { activities (sports, cooking, scientific work, languages, } \\
\text { etc.) }\end{array}$ \\
\hline
\end{tabular}

\section{Students' Personality Development}

Students at senior secondary schools are at the adolescent stage. This stage is a transition from childhood to adulthood. At this stage, students are more susceptible to psychological instability and they encounter several problems in the formation of their identity. Therefore, effective personality development must solve their problems.

The implementation of integrated education at Nur Hidayah Islamic Integrated Senior Secondary School allows for forming the intact personality of its students. Dealing with the religious spirituality aspect, the graduates of Nur Hidayah Islamic Integrated Senior secondary School implement worship as the Islamic worship rules. They intentionally understand the importance of conducting salaat and sawm, reading $\mathrm{Al}$ Quran, giving zakat, and practicing sunna as the implementation of their obedience to Allah SWT and as the way to develop their faith and piety values. Moreover, the graduates of this school are always concerned about the values of akhlaqul karimah, like being respectful to their parents, such as asking permission wherever they go, having good attitudes to society, respecting the 
teachers of Nur Hidayah Islamic Integrated Senior Secondary School although they have already graduated from the school, and greeting (salaam) other people, etc.

Intellectually, the graduates of Nur Hidayah Islamic Integrated Senior Secondary School have good habits such as reading books, conducting research, accomplishing their coursework well, joining scientific research competitions and religious or non-religious discussions, sharing their ideas in the social media or on their own blogs. In addition, they attempt to master foreign languages, especially English and Arabic, and other foreign languages to support their study. Furthermore, they have high motivation. This personality can be seen in their desire to have achievements not only in their study but also in organizations. Therefore, to obtain their desire, they try to have a healthy lifestyle and to apply high-disciplined work ethic in their coursework. Besides, the graduates of Nur Hidayah Islamic Integrated Senior secondary School are aware of problems of their people. This awareness leads them to join social events and actively participate in their campus organizations, including political and social organizations. Their involvement in those organizations makes them critical to the socio-political development of their nation.

\section{Discussion}

The integrated education implemented at Nur Hidayah Islamic Integrated Senior Secondary School is in accordance with the Indonesian national education intention to establish the intact personality of the students as intended in the Law of the National Education System Number 20 of 2003. This act states that the national education has to develop the capability, character, and civilization of the nation to enhance its intellectual capacity, and is aimed at developing learners' potentials so that they become persons imbued with human values, faithful and pious to one and only God; who possess morals and noble character; who are healthy, knowledgeable, competent, creative, independent; and as citizens, are democratic and responsible. This act is similar to the theory of integrated education, which has been discussed for a long time by pedagogues and philosophers, such as Montessori, Pestalozzi, Miller, Clark, and Rudolf Steiner, or even by ancient Greek philosophers, like Socrates and Plato. They believe that humans are made up of intellectual, emotional, spiritual, and physical elements that must be developed holistically by integrated education (Ismail \& Hassan, 2009, p. 231).

The implementation of integrated education at Nur Hidayah Islamic Integrated Senior Secondary School fulfills the basic principles of the integrated education 
theory. The principles of integrated education are in accordance with the four basic principles established by the Northern Ireland Council for Integrated Education (NICIE, 2009, pp. 3-6). These four basic principles are as follows: 1) Equality: Nur Hidayah Islamic Integrated Senior secondary School appreciates its students' potentials, respects the diversity of students' culture, and accommodates its students' multiple intelligences. 2) Instilling faith and values: In implementing the education system, Nur Hidayah Islamic Integrated Senior Secondary School creates its curriculum based on the religious values in order to instill faith and morality by using spirituality or religious values in religious activities through intra-curricular, co-curricular, extracurricular programs, and establishes cooperation with the religious leaders and figures to participate in school events. The measures taken at Nur Hidayah Islamic Integrated Senior Secondary School to internalize its students' faith values are: managing the learning process in a real-learning context, which can be applied inside and outside of the classroom; and benefitting from the school's environment (Saparudin \& Komalasari, 2015, p. 55).

3) Involving the students' parents: Nur Hidayah Islamic Integrated Senior Secondary School uses the paternalistic control model (Biedron, 2012, p. 93) as the way to involve the parents in the educational process at school. One of the aspects of their involvement is their view about the adolescent stage. They agree that at this stage their children have reached the individual maturity stage, and therefore parents should fully trust the teachers to guide them both at the school and in the school's dormitory. 4) Social responsibility: The students in this school are motivated to understand and to involve in social problem solving through non-violence conflict resolutions. The students are also required to develop their attitude of tolerance and respect in society, to improve their self-esteem and self-confidence, to respect people and preserve nature as a result of the interdependence of people and nature, to establish relationships with other schools, to create partnerships with local institutions including religious institutions, and to present the school as a common-room for the public. The rule of this social responsibility is in accordance with the theory of social interdependence, which is the basic element in the cooperative learning concept (Jablonsky, 2009, p. 21).

Thus, integrated education promotes the idea that education should be fulfilled with integrated knowledge both religious and scientific knowledge. It should make students understand that they are creatures of God and so they must obey and serve God, and carry out the mandate to preserve nature to maintain its benefits for all creatures (Lubis, et.al, 2009, p. 51). It is in accordance with the result of the research conducted by Suyatno (2013, p. 364), showing that the Islamic integrated school is willing to implement the integrated knowledge concept in its curricu- 
lum. Based on its real implementation, the Islamic integrated school is a school which applies a school administration approach, which combines both general education and religious education in its curriculum. Islamic integrated education also emphasizes the cohesiveness of its learning methods in order to optimize the cognitive, affective, and conative domains. This school also combines aqliyah, ruhiyah, and jasadiyah education. In its real implementation, this school combines the involvement and active participation of its students in their school, home, and social environment.

At the adolescent stage, the students of Senior Secondary School frequently encounter personality development problems. Makmun (2012, pp. 136-137) suggests that there are four aspects of problems usually encountered by adolescent students, namely: (1) the problem of physical and psychomotor development, such as disproportional growth of body size, voice change and menstruation, and maturation of the reproductive organs, which potentially decreases their self-confidence or even makes them develop a dependent personality; (2) the problems of language and cognitive development, such as difficulties in learning foreign languages, differences in intelligence levels, and the mismatch between the major they choose and the competence they have; (3) the problems of social awareness, morality, and religious development, such as the deviation in their peer group, conflicts with their parents, and other deviant behaviors which are not in accordance with the religious norms; and (4) the problems of conative, affective, and personality development, such as being more susceptible to bad behaviors and difficulty in being istiqamah with their conscience.

The integrated education principles at Nur Hidayah Islamic Integrated Senior Secondary School are applied through the learning process by the inquiry approach, where students participate actively in the learning process and get an opportunity to ask questions in a fun classroom atmosphere. Besides, the school pays attention to its students' unique interests and talents. The transparency with students' parents, as suggested by Latifah and Hernawati (2009, p. 39), can solve the problems related to the personality development of teenagers by developing students' intact personality in several aspects, including religious spirituality, morality, intellectuality, foreign language mastery, high motivation, leadership, healthy lifestyle, independence, high discipline, and care for social and political issues.

The guidance to the form intact personality of students in religious spirituality, morality, intellect, and emotional, social, and physical elements through religious, social, and educational institutions is one of the important parts of personality development in Islam (Smither \& Khorsandi, 2009, p. 84). According to general 
education perception, Phenix (1964) suggests some characteristics of intact personality as the personality that includes basic values, such as symbolic, ethical, esthetic, synoptic, and sinoethical ones. The result of the research conducted by Charzynska \& Wysocka (2014, pp. 203-204) shows that the concept of integrated education supported by spirituality has a positive effect on the formation of intact personality of students in order to adapt to their environment, to develop independent personality and responsibility.

\section{Conclusions}

Entering the $21^{\text {sth }}$ century, education has changed from mechanist into organist. Education is not merely viewed as a "factory" which produces "goods" but also as an institution which has a very important objective, namely: to humanize human beings. In the Law of the National Education System, the education in Indonesia basically applies integrated education in order to form intact personality in the human being. Integrated education contains basic principles, which are in accordance with the functions and objectives of national education in instilling religious spirituality, morality, intellect, nationality, independence, and physical health. In its implementation, integrated education is fully concerned about the integration of human potentials, the integration of management, the integration of the curriculum, the integration of learning domains, the integration of the three-centers of education, the integration of theory and practice, and the integration of the learning process.

\section{Acknowledgements}

This research is a grant from the Directorate General of Higher Education of the Ministry of Education of Indonesia. The author would like to express sincere appreciation for all the support provided

\section{References}

Alwasilah, A.C. (2011). Pokoknya Action Research. Bandung: Kiblat

Biedron, M. (2012). Parents' Participation in LeisureTime Activities of Their Preadolescent Child. Model Approach. Journal of The New Educational Review, 29 (3), 90-99

Charzynska, E. \& Wysocka, E. (2014). The Role of Spirituality and Belief in Free Will in the Perception of Self-efficacy Among Young Adults. Journal of The New Educational Review, 35 (2), 194-205. 
Evans, M.D. (1998). Whitehead and Philosophy of Education, Amsterdam-Atlanta.

Fan, M. (2004). The Idea of Integrated Education: From The Point Of View of Whitehead's Philosophy of Education. Paper presented at the Forum for Integrated Education and Educational Reform sponsored by the Council for Global Integrative Education, Santa Cruz, CA.

Jablonsky, T. (2009). Cooperative Learning as an Innovative Trend in Education. Journal of The New Educational Review, 19 (3-4), 17-28.

JSIT. (2010). Standar Mutu Sekolah Islam Terpadu. JSIT: Jakarta.

Ismail, H. dan Hassan, A. (2009). Holistic Education in Malaysia. European Journal of Social Sciences, 9 (2), 231-236.

Latifah, M. \& Hernawati, N. (2009). Dampak Pendidikan Holistik Pada Pembentukan Karakter Dan Kecerdasan Majemuk Anak Usia Prasekolah. Jurnal Ilmu Keluarga dan Konseling, 2 (1), 32-40.

Lubis, M.A. et.al. (2009). Integrated Islamic Education in Brunei Darussalam: Philosophical Issues and Challenges. Journal of Islamic and Arabic Education, 1 (2), 51-60.

Makmun, A.S. (2012). Psikologi Kependidikan Perangkat Sistem Pengajaran Modul. Bandung: PT. Remaja Rosda Karya.

NICIE. (2009). Statement of Principles. Retrieved 11/07/2012. From www.nicie.org/wp.../ Statement-of-Principles1.pdf.

Phenix, P.H. (1964). Realm of Meaning (a Philosophy of the Curriculum for General Education). New York: McGraw-Hill Book Company.

Rubiyanto, N. \& Haryanto, D. (2010). Stratetgi Pembelajaran Holistik di Sekolah. Jakarta: Prestasi Pustaka.

Saparudin, D. \& Komalasari, K. (2015). Living Values Education in School Habituation Program and its Effect on Student Character Development. Journal of The New Educational Review, 39 (1), 51-62. 